\title{
Kebiasaan sarapan tidak berhubungan dengan status gizi anak sekolah dasar di Kabupaten Timor Tengah Selatan, Provinsi Nusa Tenggara Timur
}

\author{
Breakfast habits did not relate with nutritional status of elementary school children in Timor Tengah \\ Selatan District, Nusa Tenggara Timur Province
}

Irma Yunawati ${ }^{1}$, Hamam Hadi², Madarina Julia ${ }^{3}$

\begin{abstract}
Background: School age children are the future generation. Improvement the quality of human resources should be done early. One of factors affecting the quality of human resources is the nutritional status. Breakfast contributes in nutritional intake (15-25\% RDA). Skipping of breakfast makes the body decreasing of glucose. It makes body to unload supplies of energy from fat tissue and cause of weight reduction.

Objectives: To determine the relationship between breakfast habits with the nutritional status of elementary school children in Nusa Tenggara Timur Province.

Methods: This was an observational study with cross-sectional design. This study used the secondary data of Alma Ata Centre for Healthy Life and Food (ACHEAF) 2013. The subjects were children from elementary school of classes between II-VI in Amanuban Barat and Kie Subdistrict, Timor Tengah Selatan District with total sample of 313 students. Sample were selected by cluster random sampling technique using computer generated random number software. Data analysis used chi-square test with a confidence interval (Cl) of $95 \%$ to the level of significance of $p<0.05$. Analysis by logistic regression was done if it showed significance result.

Results: The proportion of breakfast habits of school children was $82.11 \%$. Most widely consumed breakfast type (78,32\%) was rice (rice porridge and rice) and the other (21.68\%) were non-rice eating breakfast (bose corn, yam/cassava, boiled bananas, instant noodles, corn porridge, bread/cooky). The contribution of breakfast energy intake is $13.94 \%$ RDA and protein intake was $14.4 \%$ RDA. There was no relationship between breakfast habits and nutritional status of elementary school children.

Conclusions: Breakfast habits was not related with the nutritional status of school children in Amanuban Barat and Kie Sub-district.
\end{abstract}

KEYWORDS: breakfast habits, nutritional status, school children

\begin{abstract}
ABSTRAK
Latar belakang: Anak usia sekolah merupakan generasi penerus bangsa. Upaya peningkatan kualitas sumber daya manusia (SDM) harus dilakukan sejak dini. Salah satu faktor yang mempengaruhi kualitas SDM yaitu status gizi. Sarapan memiliki kontribusi dalam memenuhi asupan gizi, menyumbangkan 15-25\% AKG. Melewatkan sarapan membuat tubuh kekurangan glukosa sehingga tubuh membongkar persediaan tenaga dari jaringan lemak tubuh dan menyebabkan penurunan berat badan.

Tujuan: Mengetahui hubungan kebiasaan sarapan terhadap status gizi anak sekolah dasar di Kabupaten Timor Tengah Selatan Provinsi Nusa Tenggara Timur.

Metode: Jenis penelitian ini adalah observasional dengan rancangan cross sectional. Penelitian ini menggunakan data sekunder Alma Ata Centre for Healthy Life and Food (ACHEAF) 2013. Subjek
\end{abstract}

\footnotetext{
1Program Studi S2 IImu Kesehatan Masyarakat, Fakultas Kedokteran Universitas Gadjah Mada, Jl. Farmako Sekip Utara, Yogyakarta 55281, e-mail: irmayunawati@gmail.com

${ }^{2}$ Prodi S1 IImu Gizi STIKES Alma Ata Yogyakarta, Jl. Ringroad Barat Daya 1, Yogyakarta 55183

${ }^{3}$ Poliklinik Tumbuh Kembang Instansi Kesehatan Anak Rumah Sakit Umum Pusat Dr. Sardjito Yogyakarta, JI. Kesehatan No 1. Yogyakarta 55281
} 
penelitian adalah anak sekolah dasar kelas II-VI di Kecamatan Amanuban Barat dan Kie, Kabupaten Timor Tengah Selatan dengan total sampel sebanyak 313 siswa. Pengambilan sampel dilakukan dengan teknik cluster random sampling menggunakan software computer generated random number. Analisis data menggunakan uji chi-square dengan confidence interval $(\mathrm{Cl}) 95 \%$ pada tingkat kemaknaan $p<0,05$ dan hasil analisis data yang bemakna dilanjutkan dengan uji regresi logistik.

Hasil: Proporsi kebiasaan sarapan anak sekolah adalah 82,11\%. Jenis sarapan yang paling banyak dikonsumsi adalah sarapan beras (bubur nasi dan nasi) sebesar 78,32\% dan sebanyak 21,68\% mengonsumsi sarapan non-beras (jagung bose, ubi/singkong, pisang rebus, mie instan, bubur jagung, roti/kue). Kontribusi asupan energi sarapan sebesar 13,94\% AKG dan asupan protein sarapan sebesar 14,4\% AKG. Tidak ada hubungan antara kebiasaan sarapan dengan status gizi pada anak sekolah.

Kesimpulan: Kebiasaan sarapan tidak berhubungan dengan status gizi anak sekolah di Kecamatan Amanuban Barat dan Kie.

KATA KUNCI: kebiasaan sarapan, anak sekolah, status gizi

\section{PENDAHULUAN}

Anak usia sekolah merupakan generasi penerus bagi pembangunan di masa depan, sehingga perlu diupayakan peningkatan kualitas sumber daya manusia sejak dini, sistematis, dan berkesinambungan (1). Indeks pembangunan manusia (IPM) Indonesia tahun 2011 menduduki peringkat 124 , turun dari peringkat 108 di antara 187 negara pada tahun 2010 dan gizi berperan dalam pencapaian IPM tersebut $(2,3)$. Sarapan berkontribusi penting karena menyumbangkan $15-25 \%$ total asupan energi sehari $(4,5)$ atau $15-30 \%$ total asupan gizi dalam sehari untuk mewujudkan hidup sehat, aktif dan cerdas $(6,7)$. Asupan nutrisi anak yang melakukan sarapan lebih baik dibandingkan dengan anak yang melewatkan sarapan $(8,9,10)$, dan hal ini berhubungan dengan IMT normal $(4,10,11,12)$.

Melewatkan sarapan menyebabkan defisit zat gizi dan tidak dapat mengganti asupan zat gizi melalui waktu makan yang lain $(4,13,14,15)$. Seseorang yang sarapan secara konsisten cenderung memiliki status gizi yang lebih baik dibandingkan mereka yang melewatkan sarapan $(4,9,14,16)$. Sarapan yang konsisten ini dalam jangka panjang dapat memperbaiki status gizi, penambahan berat badan, dan tinggi badan khususnya pada populasi di pedesaan negaranegara berkembang $(17,18,19)$. Melewatkan sarapan membuat tubuh kekurangan glukosa sehingga tubuh menjadi lemah dan kurang konsentrasi. Akibatnya, tubuh membongkar persediaan tenaga dari jaringan lemak tubuh. Jika hal ini berlangsung secara terus menerus dapat berakibat buruk yaitu terjadinya status gizi kurang (5).

Asupan energi anak usia sekolah dasar di Indonesia yang $<70 \%$ AKG sebanyak $41,2 \%$ (20). Status gizi kurus (IMT <-2SD) pada anak usia sekolah (6-14 tahun) di Indonesia sebesar 13,3\% laki-laki dan 10,9\% perempuan (21). Di Nusa Tenggara Timur, status gizi kurus tercatat sebanyak $23,1 \%$ laki-laki dan $19,1 \%$ perempuan, sedangkan di Kabupaten Timor Tengah Selatan sebanyak 29,2\% laki-laki dan $23,0 \%$ perempuan (22). Terdapat $44,6 \%$ anak usia sekolah dasar di Indonesia yang memiliki asupan energi sarapan $<15 \%$ dan $35,4 \%$ anak yang memiliki asupan protein sarapan $<15 \%(7)$.

Sarapan memiliki kontribusi penting dalam memenuhi asupan gizi dalam sehari yang akan berdampak pada status gizi. Penelitian ini bertujuan untuk mengetahui hubungan kebiasaan sarapan terhadap status gizi pada anak usia sekolah.

\section{BAHAN DAN METODE}

Jenis penelitian ini adalah observasional dengan rancangan cross sectional. Penelitian ini menggunakan data sekunder Alma Ata Centre for Healthy Life and Food (ACHEAF) tahun 2013. Subjek penelitian adalah anak sekolah dasar kelas II-VI di Kecamatan Amanuban Barat dan Kie, Kabupaten Timor Tengah Selatan dengan total sampel sebanyak 313 siswa. Pengambilan sampel dilakukan dengan teknik cluster random sampling menggunakan software computer generated random number. 
Peneliti mengumpulkan data anak sekolah beserta walinya sesuai dengan kriteria inklusi yang telah ditetapkan yaitu berada di kelas II-VI sekolah dasar, tercatat sebagai siswa di sekolah yang terpilih dalam penelitian, wali murid dan anak bersedia untuk berpartisipasi dalam penelitian. Data tidak diambil jika anak mengalami kelainan kongenital atau cacat fisik dan dalam keadaan sakit/kondisi fisik yang mengganggu proses belajarnya.

Variabel pada penelitian ini terdiri dari variabel bebas yaitu kebiasaan sarapan, variabel antara yaitu asupan energi dan protein perhari, variabel terikat yaitu status gizi (IMT/U) dan variabel luar yaitu jenis sarapan dan karakteristik keluarga yang meliputi: pekerjaan, pendidikan terakhir ayah dan ibu, serta jumlah anak dalam rumah tangga.

Data kebiasaan sarapan, jenis sarapan serta karakteristik keluarga meliputi: pekerjaan ayah dan ibu, pendidikan terakhir ayah dan ibu serta jumlah anak dalam keluarga dikumpulkan menggunakan kuesioner terstruktur yang ditanyakan oleh enumerator kepada subjek penelitian yaitu anak sekolah dan ibu dari subjek penelitian. Data status gizi diperoleh dari IMT/U dengan cut off Z-score rujukan WHO 2005 yang diolah menggunakan WHO Anthroplus. Data gambaran asupan energi dan protein dikumpulkan menggunakan formulir food recall 1x24 jam yang ditanyakan oleh enumerator kepada anak sekolah dan diolah menggunakan Nutrisurvey. Data berat badan diperoleh dengan mengukur berat badan anak sekolah oleh enumerator menggunakan timbangan injak digital dengan ketelitian $0,1 \mathrm{~kg}$ dan data tinggi badan diperoleh dengan mengukur tinggi badan anak sekolah oleh enumerator menggunakan microtoise dengan ketelitian $0,1 \mathrm{~cm}$. Data jumlah siswa diperoleh dari Dinas Pendidikan Kecamatan Amanuban Barat dan Kie dan data tentang gambaran umum lokasi penelitian diperoleh dari Kantor Kecamatan Amanuban Barat dan Kie.

Data dianalisis dengan menggunakan perangkat lunak komputer khusus untuk analisis statistik secara univariat yaitu distribusi frekuensi dan analisis bivariat dengan uji chi-square dengan confidence interval (Cl) $95 \%$ pada tingkat kemaknaan $p<0,05$ dan hasil analisis data yang bemakna dilanjutkan dengan uji regresi logistik. Penelitian ini dilakukan setelah mendapat surat kelayakan etik dari Komisi Etik Penelitian Kedokteran dan Kesehatan Fakultas Kedokteran Universitas Gadjah Mada dengan nomor Ref: KE/FK/382/EC tahun 2014.

\section{HASIL}

Responden anak sekolah sebanyak 313 orang yang berasal dari 14 sekolah dasar di Kecamatan Amanuban Barat dan Kie. Responden penelitian ini adalah anak sekolah kelas II-VI. Tidak ada responden dari kelas I karena pengambilan data dilakukan pada akhir tahun akademik sehingga belum menerima siswa baru untuk menjadi siswa kelas I. Jumlah responden anak sekolah di Kecamatan Amanuban Barat sebanyak 145 anak dan di Kecamatan Kie sebanyak 168 anak. Jumlah responden berjenis kelamin laki-laki sebanyak 140 anak $(44,73 \%)$ dan perempuan sebanyak 173 anak $(55,27 \%)$. Umur anak 6-9 tahun sebanyak 172 anak (54,95\%), 10-12 tahun sebanyak 125 anak (39,94\%) dan $\geq 13$ tahun sebanyak 16 anak $(5,11 \%)$. Jumlah anak yang duduk di kelas II sebanyak 24 anak $(7,67 \%)$, kelas III sebanyak 106 anak $(33,87 \%)$, kelas IV sebanyak 66 anak $(21,09 \%)$, kelas $\mathrm{V}$ sebanyak 62 anak $(19,81 \%)$ dan kelas VI sebanyak 55 anak (17,57\%).

Kebiasaan sarapan pada anak sekolah dalam penelitian ini terbilang tinggi. Lebih dari $80 \%$ anak sekolah menyatakan biasa sarapan di rumah sebelum berangkat ke sekolah dengan jenis makanan yang banyak dikonsumsi adalah makanan dalam kategori beras $(78,32 \%)$ dan dari kategori beras tersebut, sebagian besar anak sekolah mengonsumsi bubur nasi (Tabel 1).

Sebagian besar asupan energi dan protein sarapan anak sekolah masih dalam kualitas rendah karena termasuk dalam kategori kurang, yaitu asupan energi dan protein sarapan $<15 \%$ AKG. Persentase asupan energi sarapan pada responden yang $<15 \%$ AKG sebanyak $71,25 \%$ dan asupan protein sarapan yang $<15 \%$ AKG sebanyak $65,81 \%$. Demikian pula untuk asupan energi dan protein per hari $<70 \%$ AKG, yang tercatat persentase asupan energi per hari $<70 \%$ AKG sebanyak $83,07 \%$, 
Tabel 1. Karakteristik anak sekolah dan orang tua, kebiasaan dan jenis sarapan

\begin{tabular}{|c|c|c|}
\hline $\begin{array}{c}\text { Karakteristik anak sekolah dan } \\
\text { orangtua }\end{array}$ & $\mathbf{n}$ & $\%$ \\
\hline $\begin{array}{l}\text { Pendidikan ibu* } \\
\text { Rendah } \\
\text { Tinggi }\end{array}$ & $\begin{array}{c}276 \\
35\end{array}$ & $\begin{array}{l}88,75 \\
11,25\end{array}$ \\
\hline $\begin{array}{l}\text { Pendidikan ayah** } \\
\text { Rendah } \\
\text { Tinggi }\end{array}$ & $\begin{array}{c}253 \\
59\end{array}$ & $\begin{array}{l}81,09 \\
18,91\end{array}$ \\
\hline $\begin{array}{l}\text { Pekerjaan ibu* } \\
\text { Tidak bekerja/ IRT } \\
\text { Bekerja }\end{array}$ & $\begin{array}{c}261 \\
50\end{array}$ & $\begin{array}{l}83,92 \\
16,08\end{array}$ \\
\hline $\begin{array}{l}\text { Pekerjaan ayah** } \\
\text { Petani/peternak/nelayan/buruh } \\
\text { Karyawan swasta/ PNS/ TNI/ } \\
\text { POLRI/ wiraswasta/lainnya }\end{array}$ & $\begin{array}{c}264 \\
48\end{array}$ & $\begin{array}{l}84,62 \\
15,38\end{array}$ \\
\hline $\begin{array}{l}\text { Jumlah anak dalam keluarga } \\
\quad>2 \text { orang } \\
\quad \leq 2 \text { orang }\end{array}$ & $\begin{array}{c}246 \\
67\end{array}$ & $\begin{array}{l}78,59 \\
21,41\end{array}$ \\
\hline $\begin{array}{l}\text { Kebiasaan sarapan } \\
\text { Tidak biasa sarapan } \\
\text { Biasa sarapan }\end{array}$ & $\begin{array}{c}56 \\
257\end{array}$ & $\begin{array}{l}17,89 \\
82,11\end{array}$ \\
\hline $\begin{array}{l}\text { Jenis sarapan } \\
\text { Non beras } \\
\text { Beras }\end{array}$ & $\begin{array}{c}67 \\
242\end{array}$ & $\begin{array}{l}21,68 \\
78,32\end{array}$ \\
\hline $\begin{array}{l}\text { Non beras } \\
\text { Pisang rebus } \\
\text { Jagung bose } \\
\text { Ubi/singkong } \\
\text { Mie instan } \\
\text { Lainnya**** }\end{array}$ & $\begin{array}{c}1 \\
39 \\
8 \\
1 \\
18\end{array}$ & $\begin{array}{c}0,32 \\
12,62 \\
2,59 \\
0,32 \\
5,83\end{array}$ \\
\hline $\begin{array}{l}\text { Beras } \\
\text { Nasi } \\
\text { Bubur nasi }\end{array}$ & $\begin{array}{c}46 \\
196\end{array}$ & $\begin{array}{l}14,89 \\
63,43\end{array}$ \\
\hline
\end{tabular}

Keterangan:

* Jumlah responden ibu sebanyak 311 responden (Amanuban Barat: 145, Kie: 166). Dua subjek anak sekolah tidak tinggal bersama ibunya disebabkan ibu yang meninggal

** Jumlah responden ayah sebanyak 312 responden (Amanuban Barat: 146, Kie: 166). Satu subjek anak sekolah tidak tinggal bersama ayahnya disebabkan ayah yang meninggal

*** Jumlah responden pada variabel jenis sarapan sebanyak 309 responden (Amanuban Barat: 144, Kie: 165). Empat subjek anak sekolah tidak memiliki jenis sarapan yang biasa dikonsumsi disebabkan anak tersebut tidak pernah sarapan

**** Jenis sarapan untuk lainnya meliputi: bubur jagung, roti/kue dan asupan protein per hari $<70 \%$ AKG sebanyak $68,05 \%$. Meskipun demikian, sebagian besar status gizi anak sekolah cukup baik yaitu terdapat $78,27 \%$ dalam kategori normal.

Kontribusi asupan gizi dari sarapan anak sekolah masih dalam kategori kurang, yaitu $<15 \%$ AKG yang dianjurkan. Rata-rata asupan energi sarapan sebesar 13,94\% AKG (251 kkal) dan ratarata asupan protein sarapan sebesar $14,40 \%$ AKG $(6,48 \mathrm{~g})$. Asupan energi dan protein sarapan ini mempengaruhi asupan energi dan protein per hari. Asupan energi per hari sebesar 55,72\% AKG (1.003 kkal) dan asupan protein per hari sebesar $66,04 \%$ AKG $(29,72 \mathrm{~g})$. Asupan ini masih kurang dari asupan gizi yang dianjurkan sebesar $\geq 70 \%$ AKG.

Jika dilihat dari kebiasaan sarapan, maka asupan energi dan protein sarapan lebih besar pada anak yang biasa sarapan, meskipun masih $<15 \%$ AKG. Anak sekolah yang biasa sarapan memiliki asupan energi sebesar $14,22 \%$ AKG (256 kkal) dan asupan protein sebesar 14,44\% AKG (6,5 g), sedangkan anak yang tidak biasa sarapan memiliki asupan energi sarapan sebesar $12,77 \%$ AKG (230 kkal) dan asupan protein sebesar $13,55 \%$ AKG $(6,1$ g). Hal ini mempengaruhi asupan energi dan protein per hari. Anak yang biasa sarapan memiliki asupan energi per hari sebesar 56,50\% AKG (1.017 kkal) dan asupan protein per hari sebesar $66,44 \%$ AKG $(29,9 \mathrm{~g})$, sedangkan anak yang tidak biasa sarapan memiliki asupan gizi lebih rendah yaitu asupan energi per hari sebesar 52,22\% AKG (940 kkal) dan asupan protein per hari sebesar $63,77 \%$ AKG $(28,7 \mathrm{~g})$. Meskipun demikian, asupan per hari anak sekolah yang biasa sarapan dan tidak biasa sarapan masih sangat kurang yaitu $<70 \%$ AKG.

Hasil uji statistik menunjukkan ada perbedaan kebiasaan sarapan antara Kecamatan Amanuban Barat dan Kie $(p=0,04)$ (Tabel 2). Penelitian ini juga menunjukkan proporsi anak sekolah yang memiliki status gizi kurus sebesar $21,73 \%$. Jika dibagi berdasarkan kecamatan, proporsi anak sekolah kurus di Kecamatan Amanuban Barat (23,97\%) lebih tinggi dibandingkan dengan Kecamatan Kie (19,76\%).

Persentase anak sekolah dengan status gizi normal yang biasa sarapan sebesar $83,27 \%$ dan hasil uji statistik menunjukkan bahwa kebiasaan 
Tabel 2. Karakteristik responden menurut kebiasaan sarapan dan asupan zat gizi berdasarkan kecamatan

\begin{tabular}{|c|c|c|c|c|c|c|c|}
\hline \multirow{3}{*}{ Karakteristik responden } & \multicolumn{4}{|c|}{ Kecamatan } & & \multirow{3}{*}{$\mathbf{p}$} & \multirow{3}{*}{$\begin{array}{c}\text { RP } \\
(95 \% \mathrm{Cl})\end{array}$} \\
\hline & \multicolumn{2}{|c|}{ Amanuban Barat } & \multicolumn{2}{|c|}{ Kie } & & & \\
\hline & $\mathbf{n}$ & $\%$ & $\mathbf{n}$ & $\%$ & & & \\
\hline \multicolumn{8}{|l|}{ Kebiasaan sarapan } \\
\hline Tidak biasa sarapan & 33 & 22,60 & 23 & 13,77 & 4,13 & 0,04 & 1,11 \\
\hline Biasa sarapan & 113 & 77,40 & 144 & 86,23 & & & $(1,00-1,23)$ \\
\hline \multicolumn{8}{|l|}{ Asupan energi sarapan } \\
\hline Kurang & 106 & 72,60 & 117 & 70,06 & 0,24 & 0,62 & 1,09 \\
\hline Cukup & 40 & 27,40 & 50 & 29,94 & & & $(0,77-1,55)$ \\
\hline \multicolumn{8}{|l|}{ Asupan protein sarapan } \\
\hline Kurang & 94 & 64,38 & 112 & 67,07 & 0,25 & 0,62 & 0,92 \\
\hline Cukup & 52 & 35,62 & 55 & 32,93 & & & $(0,68-1,26)$ \\
\hline \multicolumn{8}{|l|}{ Asupan energi per hari } \\
\hline Kurang & 125 & 85,62 & 135 & 80,84 & 1,26 & 0,26 & 1,33 \\
\hline Cukup & 21 & 14,38 & 32 & 19,16 & & & $(0,80-2,20)$ \\
\hline \multicolumn{8}{|l|}{ Asupan protein per hari } \\
\hline Kurang & 105 & 71,92 & 108 & 64,67 & 1,88 & 0,17 & 1,26 \\
\hline Cukup & 41 & 28,08 & 59 & 35,33 & & & $(0,90-1,75)$ \\
\hline
\end{tabular}

*) Bermakna $p<0,05$

sarapan tidak memiliki hubungan yang bermakna dengan status gizi anak sekolah $(p>0,05)$. Asupan gizi juga tidak menunjukkan hubungan yang bermakna dengan status gizi $(p>0,05)$. Persentase anak sekolah dengan status gizi kurus yang memiliki asupan energi dan protein sarapan kategori kurang $(<15 \%$ AKG) masing-masing sebesar $79,41 \%$ dan $69,12 \%$, sedangkan untuk anak sekolah dengan status gizi kurus yang memiliki asupan energi dan protein per hari kategori kurang $(<70 \%$ AKG) sebesar $86,76 \%$ dan $73,53 \%$ (Tabel 3 ).
Anak sekolah yang biasa sarapan dengan status gizi kurus maupun normal sebagian besar asupan energi dan protein sarapan $<15 \%$ AKG dan asupan energi dan protein per hari sebagian besar $<70 \%$ AKG. Anak yang memiliki kebiasaan sarapan namun jumlahnya kurang akan mengalami gizi kurus dalam jangka waktu lama. Pendidikan dan pekerjaan orang tua, jumlah anak dalam keluarga, dan jenis sarapan tidak terbukti berhubungan dengan status gizi anak sekolah $(p>0,05)$ (Tabel 4).

Tabel 3. Hubungan kebiasaan sarapan dan asupan gizi dengan status gizi

\begin{tabular}{|c|c|c|c|c|c|c|c|}
\hline \multirow{3}{*}{ Variabel } & \multicolumn{4}{|c|}{ Status gizi } & \multirow{3}{*}{$\chi^{2}$} & \multirow{3}{*}{ p } & \multirow{3}{*}{$\begin{array}{c}\text { RP } \\
(95 \% \mathrm{CI})\end{array}$} \\
\hline & \multicolumn{2}{|c|}{ Kurus } & \multicolumn{2}{|c|}{ Normal } & & & \\
\hline & $\mathbf{n}$ & $\%$ & $\mathbf{n}$ & $\%$ & & & \\
\hline \multicolumn{8}{|l|}{ Kebiasaan sarapan } \\
\hline Tidak biasa sarapan & 15 & 22,06 & 41 & 16,73 & & & 1,07 \\
\hline Biasa sarapan & 53 & 77,94 & 204 & 83,27 & 1,03 & 0,31 & $(0,93-1,23)$ \\
\hline \multicolumn{8}{|l|}{ Asupan energi sarapan } \\
\hline Kurang & 54 & 79,41 & 169 & 68,98 & 2,83 & 0,09 & 1,50 \\
\hline Cukup & 14 & 20,59 & 76 & 31,02 & & & $(0,91-2,49)$ \\
\hline \multicolumn{8}{|l|}{ Asupan protein sarapan } \\
\hline Kurang & 47 & 69,12 & 159 & 64,90 & 0,42 & 0,52 & 1,17 \\
\hline Cukup & 21 & 30,88 & 86 & 35,10 & & & $(0,76-1,68)$ \\
\hline \multicolumn{8}{|l|}{ Asupan energi per hari } \\
\hline Kurang & 59 & 86,76 & 201 & 82,04 & 0,84 & 0,36 & 1,36 \\
\hline Cukup & 9 & 13,24 & 44 & 17,96 & & & $(0,69-2,64)$ \\
\hline \multicolumn{8}{|l|}{ Asupan protein per hari } \\
\hline Kurang & 50 & 73,53 & 163 & 66,53 & 1,20 & 0,27 & 1,26 \\
\hline Cukup & 18 & 26,47 & 82 & 33,47 & & & $(0,82-1,95)$ \\
\hline
\end{tabular}


Hasil analisis statistik menunjukkan bahwa pendidikan orang tua, pekerjaan ayah, jumlah anak dalam keluarga, dan jenis sarapan tidak mempengaruhi kebiasaan sarapan pada anak sekolah $(p>0,05)$. Dilihat dari pekerjaan ibu, persentase anak sekolah yang memiliki kebiasaan sarapan dengan ibu yang tidak bekerja sebesar $85,88 \%$. Pekerjaan ibu memiliki hubungan yang bermakna dengan kebiasaan sarapan anak sekolah $(p=0,04)$.
Uji statistik multivariat menunjukkan kebiasaan sarapan tidak berhubungan bermakna dengan status gizi pada anak sekolah $(\mathrm{OR}=1,51,95 \% \mathrm{Cl}: 0,76-3,02)$ setelah mengontrol variabel-variabel luar yang memiliki nilai $p<0,25$ pada analisis bivariat. Begitu pula variabel luar yang dikontrol yaitu variabel jenis sarapan dan asupan energi sarapan juga tidak berhubungan signifikan dengan status gizi anak sekolah (Tabel 5).

Tabel 4. Hubungan variabel luar dengan status gizi

\begin{tabular}{|c|c|c|c|c|c|c|c|}
\hline \multirow{3}{*}{ Variabel } & \multicolumn{4}{|c|}{ Status gizi } & \multirow{3}{*}{$\chi^{2}$} & \multirow{3}{*}{$\mathbf{p}$} & \multirow{3}{*}{$\begin{array}{c}\text { RP } \\
(95 \% \mathrm{Cl})\end{array}$} \\
\hline & \multicolumn{2}{|c|}{ Kurus } & \multicolumn{2}{|c|}{ Normal } & & & \\
\hline & $\mathbf{n}$ & $\%$ & $\mathbf{n}$ & $\%$ & & & \\
\hline \multicolumn{8}{|l|}{ Pendidikan ibu } \\
\hline Rendah & 59 & 88,06 & 217 & 88,93 & 0,04 & 0,84 & 0,93 \\
\hline Tinggi & 8 & 11,94 & 27 & 11,07 & & & $(0,44-1,94)$ \\
\hline \multicolumn{8}{|l|}{ Pendidikan ayah } \\
\hline Rendah & 54 & 79,41 & 199 & 81,56 & 0,16 & 0,69 & 0,89 \\
\hline Tinggi & 14 & 20,59 & 45 & 18,44 & & & $(0,52-1,53)$ \\
\hline \multicolumn{8}{|l|}{ Pekerjaan ibu } \\
\hline Tidak bekerja/ IRT & 54 & 80,60 & 207 & 84,84 & 0,70 & 0,40 & 0,78 \\
\hline Bekerja & 13 & 19,40 & 37 & 15,16 & & & $(0,44-1,38)$ \\
\hline \multicolumn{8}{|l|}{ Pekerjaan ayah } \\
\hline Petani/peternak/nelayan/buruh & 56 & 82,35 & 208 & 85,25 & 0,34 & 0,56 & 0,84 \\
\hline $\begin{array}{l}\text { Karyawan swasta/ PNS/ TNI/ POLRI/ } \\
\text { wiraswasta/Lainnya }\end{array}$ & 12 & 17,65 & 36 & 14,75 & & & $(0,46-1,52)$ \\
\hline \multicolumn{8}{|l|}{ Jumlah anak dalam keluarga } \\
\hline$>2$ orang & 54 & 79,41 & 192 & 78,37 & 0,03 & 0,85 & 1,05 \\
\hline$\leq 2$ orang & 14 & 20,59 & 53 & 21,63 & & & $(0,62-1,77)$ \\
\hline \multicolumn{8}{|l|}{ Jenis sarapan } \\
\hline Non beras & 10 & 14,93 & 57 & 23,55 & 2,30 & 0,13 & 0,89 \\
\hline Beras & 57 & 85,07 & 185 & 76,45 & & & $(0,79-1,01)$ \\
\hline
\end{tabular}

Tabel 5. Hasil uji multivariat kebiasaan sarapan dengan status gizi

\begin{tabular}{|c|c|c|}
\hline Variabel & $\begin{array}{c}\text { Model } 1 \\
\text { OR } \\
(95 \% \mathrm{Cl}) \\
\end{array}$ & $\begin{array}{c}\text { Model } 2 \\
\text { OR } \\
(95 \% \mathrm{Cl})\end{array}$ \\
\hline \multicolumn{3}{|l|}{ Kebiasaan sarapan } \\
\hline Tidak biasa sarapan & $\begin{array}{c}1,37 \\
(0,68-2,78)\end{array}$ & $\begin{array}{c}1,51 \\
(0,76-3,02)\end{array}$ \\
\hline Biasa sarapan & 1 & 1 \\
\hline \multicolumn{3}{|l|}{ Jenis sarapan } \\
\hline Non beras & $\begin{array}{c}0,56 \\
(0,27-1,18)\end{array}$ & $\begin{array}{c}0,54 \\
(0,26-1,14)\end{array}$ \\
\hline Beras & 1 & 1 \\
\hline \multicolumn{3}{|l|}{ Asupan energi sarapan } \\
\hline Kurang baik & $\begin{array}{c}1,59 \\
(0,82-3,08)\end{array}$ & \\
\hline Baik & 1 & \\
\hline
\end{tabular}

Keterangan:

Status gizi (0: Kurus, 1: Normal) 


\section{BAHASAN}

Penelitian ini menemukan proporsi kebiasaan sarapan pada anak sekolah sangat tinggi. Jenis sarapan yang lebih banyak dikonsumsi oleh anak sekolah ketika sarapan adalah jenis makanan kategori beras (bubur nasi dan nasi) dibandingkan jenis sarapan non beras (jagung bose, ubi/singkong, pisang rebus, mie instan, dan makanan lainnya (bubur jagung, roti/kue) (Tabel 1). Anak sekolah yang tidak biasa sarapan paling banyak berusia 1012 tahun dan perempuan lebih banyak yang tidak sarapan dibanding laki-laki. Kebiasaan melewatkan sarapan meningkat dengan bertambahnya usia $(16,23,24)$, terutama perempuan $(25)$.

Kebiasaan sarapan anak sekolah di Kecamatan Kie lebih baik dibandingkan anak sekolah di Kecamatan Amanuban Barat (Tabel 2). Hal ini bisa disebabkan faktor jarak antara rumah dan sekolah yang cukup jauh dibandingkan dengan jarak rumah ke sekolah yang ada di Kecamatan Amanuban Barat. Faktor jarak ini menyebabkan anak sekolah di Kecamatan Kie melakukan sarapan di rumah. Selain itu, faktor lainnya adalah tidak adanya kantin maupun warung yang ada di sekolah, sehingga anak sekolah yang tidak sarapan di rumah akan merasa lelah dan lapar yang pada akhirnya bisa berpengaruh pada konsentrasi yang kurang optimal.

Hasil penelitian ini juga menunjukkan bahwa pekerjaan ibu berhubungan dengan kebiasaan sarapan anak sekolah (Tabel 3). Hal ini disebabkan ibu yang tidak bekerja (IRT) memiliki lebih banyak waktu dalam menyiapkan menu sarapan untuk anak sekolah, sehingga anak dapat sarapan dengan baik dan tidak terburu-buru. Sarapan sebagai sumber energi untuk aktivitas harian sebaiknya disiapkan lebih pagi agar anak dapat sarapan dengan waktu yang lebih panjang dan tidak tergesa-gesa. Ketergesa-gesaan tidak baik untuk pencernaan karena dapat membuat anak tersedak atau muntah (26). Hal ini berbeda dengan kebiasaan sarapan anak sekolah di perkotaan yang lebih rendah, karena di perkotaan sebagian besar anak memiliki kebiasaan tidak sarapan yang seringkali disebabkan kesibukan ibu bekerja dan waktu yang amat terbatas di pagi hari karena harus meninggalkan rumah (27).

Kebiasaan sarapan tidak berhubungan bermakna dengan status gizi $(p>0,05)$ (Tabel 3). Hal ini dapat disebabkan oleh beberapa hal, seperti pengetahuan orang tua, serta kualitas dan kuantitas asupan energi dan protein sarapan yang rendah. Pengetahuan orang tua, terutama ibu dapat mempengaruhi tindakan yang akan dilakukan terhadap anak dan keluarga mereka. Pengetahuan atau kognitif merupakan domain yang sangat penting untuk terbentuknya tindakan seseorang. Perilaku yang didasari oleh pengetahuan akan lebih langgeng daripada perilaku yang tidak didasari oleh pengetahuan (28).

Kualitas asupan sarapan yang rendah disebabkan kurangnya variasi makanan untuk sarapan. Sebagian besar anak sekolah hanya mengonsumsi bubur nasi/ nasi tanpa ada jenis makanan yang lain. Makanan yang mengandung protein seperti telur, daging, ikan serta sayursayuran juga jarang dikonsumsi oleh anak sekolah. Hal ini mempengaruhi asupan zat gizi anak sekolah karena bubur nasi/ nasi lebih banyak mengandung karbohidrat, sedangkan kandungan zat gizi lain sangat kecil. Faktor yang mempengaruhi kualitas sarapan anak sekolah ini bisa disebabkan kesulitan ibu dalam membeli bahan makanan di pasaran karena harganya yang mahal (keadaan ekonomi keluarga rendah). Faktor lain yang berpengaruh adalah kebersihan makanan yang dikonsumsi anak. Faktor kebersihan merupakan salah satu faktor penting dalam pemberian makan kepada anak (29).

Kuantitas asupan energi dan protein sarapan pada anak yang biasa sarapan dan tidak biasa sarapan dalam penelitian ini masih rendah yaitu $<15 \%$ AKG. Hasil penelitian ini juga menunjukkan tidak ada hubungan antara asupan energi dan protein sarapan serta asupan energi dan protein per hari dengan status gizi (Tabel 3). Dalam usaha pencapaian konsumsi yang adekuat, maka dua faktor terpenting yang dapat mempengaruhi konsumsi zat gizi adalah tersedianya pangan dan pengetahuan gizi. Seseorang akan mampu menyelenggarakan konsumsi yang adekuat bila 
mereka mampu menyediakan bahan pangan karena didukung oleh pandangan yang cukup. Zat gizi yang telah dikonsumsi tersebut akan digunakan oleh tubuh untuk mencapai status gizi optimal (30).

Faktor yang mempengaruhi status gizi bukan hanya dipengaruhi oleh asupan, apalagi hanya dari asupan energi dan protein. Asupan energi dan protein yang didasarkan pada angka kecukupan gizi sebagian memang cukup disebabkan kecukupan gizi merupakan kebutuhan rata-rata suatu kelompok umur yang sudah dibakukan, namun terkadang tidak mencerminkan kebutuhan masing-masing individu. Bukan hanya dari asupan energi dan protein saja yang dapat berpengaruh terhadap status gizi, zat gizi lain juga sangat berperan penting. Faktor penyakit infeksi, jangkauan dan kualitas pelayanan kesehatan, pola asuh anak, sanitasi lingkungan dan ketahanan pangan di tingkat rumah tangga juga mempengaruhi status gizi (31).

Dalam penelitian ini, karakteristik keluarga dan jenis sarapan tidak berhubungan bermakna dengan status gizi pada anak sekolah (Tabel 4). Pendidikan ibu dan ayah tidak berpengaruh terhadap status gizi anak sekolah karena bisa disebabkan oleh tingkat pengetahuan mereka tentang gizi yang tidak berkaitan dengan pendidikan terakhir yang telah diperoleh. Hal tersebut berpengaruh terhadap pola pengasuhan terhadap anak. Selain itu, jangkauan dan kualitas pelayanan kesehatan serta petugas kesehatan yang ada di Kecamatan Amanuban Barat dan Kie turut mempengaruhi status gizi kesehatan. Petugas kesehatan berperan penting dalam memberi informasi (pengetahuan) tentang kesehatan termasuk status gizi anak sekolah. Faktor pemungkin yang mempengaruhi tindakan seseorang adalah tersedianya fasilitas atau sarana prasarana kesehatan serta keterampilan yang berhubungan dengan kesehatan, termasuk peran petugas kesehatan (28).

Pada penelitian ini, jenis pekerjaan ibu dan ayah, serta jumlah anak tidak berhubungan dengan status gizi anak sekolah (Tabel 4). Hal ini bisa disebabkan beberapa faktor lain yaitu: ketersediaan pangan yang ada belum tentu dapat mencukupi kebutuhan bagi penduduk di lokasi tersebut atau harga jual tidak dapat terjangkau oleh masyarakat (lokasi jauh dari Kota Soe menyebabkan harga relatif mahal) sehingga berpengaruh terhadap tingkat konsumsi mereka. Selain itu, kondisi ekonomi sebagian besar masyarakat yang rendah akan menyulitkan masyarakat membeli makanan sehingga distribusi makanan di tingkat rumah tangga tidak merata. Distribusi makanan yang tidak merata akan mempengaruhi tingkat konsumsi, keragaman makanan serta asupan zat gizi yang ada dalam keluarga. Begitu pula jenis sarapan tidak berpengaruh terhadap status gizi, bisa disebabkan terbatasnya persediaan sumber karbohidrat jenis beras yang bukan merupakan bahan makanan lokal sehingga terjadi ketidakmampuan dalam membeli jenis bahan makanan tersebut.

Pada penelitian ini tidak diteliti faktor pendapatan orang tua yang kemungkinan dapat berdampak pada daya beli untuk memenuhi asupan gizi. Faktor ekonomi merupakan suatu penentu status gizi yang dapat mempengaruhi status gizi anak. Status ekonomi yang rendah atau kemiskinan menduduki posisi pertama pada masyarakat yang menyebabkan gizi kurang (32). Keadaan ekonomi keluarga yang baik dapat menjamin terpenuhinya kebutuhan pokok setiap anggota keluarga (33). Status sosial ekonomi mempengaruhi status gizi anak. Status sosial ekonomi rendah adalah faktor risiko terjadinya kekurusan pada anak sekolah (34).

\section{KESIMPULAN DAN SARAN}

Proporsi kebiasaan sarapan anak sekolah secara keseluruhan adalah $82,11 \%$. Proporsi kebiasaan sarapan anak sekolah dengan persentase lebih banyak di Kecamatan Kie $(86,23 \%)$ dibandingkan di Amanuban Barat $(77,40 \%)$. Sebagian besar jenis makanan yang dikonsumsi oleh anak sekolah ketika sarapan yaitu jenis makanan olahan beras $(78,32 \%)$. Sebesar $(21,68 \%)$ lainnya mengonsumsi jenis sarapan non beras (jagung bose, ubi/ singkong, pisang rebus, mie instan, dan makanan lainnya (bubur jagung, roti/ kue).

Anak sekolah dasar di Kecamatan Amanuban Barat dan Kie mengonsumsi sarapan dengan kualitas rendah yaitu asupan energi dan protein 
$<15 \%$ AKG, dengan kontribusi asupan energi dan protein sarapan masing-masing $13,94 \%$ AKG dan $14,4 \%$ AKG. Tidak ada hubungan antara kebiasaan sarapan dengan status gizi pada anak sekolah.

Penelitian lanjutan perlu dilakukan, misalnya rancangan longitudinal dengan penilaian asupan makan food frequency questionnaire (FFQ) atau food record atau dengan klasifikasi status gizi berdasarkan BB/U dan TB/U. Bagi Pemerintah Kabupaten TTS agar memperhatikan dan menjamin akses masyarakat terhadap makanan karena mahalnya harga makanan di desa-desa yang berlokasi jauh dari Kota Soe. Kondisi ekonomi sebagian besar masyarakat yang rendah akan menyulitkan masyarakat membeli makanan sehingga distribusi makanan di tingkat rumah tangga tidak merata. Distribusi makanan yang tidak merata akan mengurangi asupan zat gizi, sehingga mempengaruhi status gizi. Sebaiknya pula kerjasama antara tenaga kesehatan, komponen masyarakat, pihak sekolah dan stakeholder perlu ditingkatkan dalam memberikan edukasi, terutama bagi ibu berkaitan dengan pola asuh anak dan gizi, seperti pentingnya kebiasaan sarapan anak sekolah.

\section{RUJUKAN}

1. Judarwanto W. Perilaku makan anak sekolah. Jakarta: Picky Eaters Clinic; 2009.

2. United Nations Development Programme (UNDP). Human development report 2011 (sustainability and equity: a better future for all). New York: United Nations Development Programme (UNDP); 2011.

3. Badan Perencanaan Pembangunan Nasional. Rencana aksi nasional pangan dan gizi 2011-2015. Jakarta: Badan Perencanaan Pembangunan Nasional; 2011.

4. Rampersaud G, Pereira M, Girard B, Adams J, Metzl J. Breakfast habits, nutritional status, body weight, and academic performance in children and adolescents. J Am Diet Assoc. 2005;105(5):743-60.

5. Khomsan A. Pangan dan gizi untuk kesehatan 2. Bogor: Departemen Gizi Masyarakat, Fakultas Ekologi Manusia, Institut Pertanian Bogor; 2005.
6. Pereira M, Erickson E, Mckee P, Schrankler K, Raatz S, Lytle L, et al. Breakfast frequency and quality may affect glycemia and appetite in adults and children. J Nutr. 2011;141:163S $8 \mathrm{~S}$.

7. Hardinsyah, Aries M. Jenis pangan sarapan dan perannya dalam asupan gizi harian anak usia 6-12 tahun di Indonesia. J GIZI PANGAN. 2012;7(2):89-96.

8. Wahba S, Mekawy A, Ahmed R, Mohsen W. Breakfast skipping and dietary adequacy of primary school children in Cairo. J Appl Sci Res. 2006;2(1):51-7.

9. Chitra $U$, Reddy C. The role of breakfast in nutrient intake of urban school children. Public Health Nutr. 2007;10(1):55-8.

10. Dubois L, Girard M, Kent M, Farmer A, TatoneTokuda $F$. Breakfast skipping is associated with differences in meal patterns, macronutrient intakes and overweight among pre-school children. Public Health Nutr. 2008;12(1):19-28.

11. Hidayat M. Sarapan ditinjau dari sudut ilmu gizi. Maj IIm Maranatha. 2009;16(2):53-8.

12. Aziz M, Devi M. Nutritional status and eating practices among children aged 4-6 years old in selected urban dan rural kindergarten in Selangor, Malaysia. Asian J Clin Nutr. 2012;4(4):116-31.

13. Ruxton C, Kirk T. Breakfast: a Review of associations with measures of dietary intake, physiology and biochemistry. Br J Nutr. 1997;78:199-213.

14. Nicklas T, O'Neil C, Berenson G. Nutrient contribution of breakfast, secular trends, and the role of ready-to-eat cereals: a review of data from the bogalusa heart study. Am J Clin Nutr. 1998;67:757S - 63S.

15. Soedibyo S, Gunawan H. Kebiasaan sarapan di kalangan anak usia sekolah dasar di poliklinik umum Departemen Ilmu Kesehatan Anak FKUIRSCM. Sari Pediatr. 2009;11(1):66-70.

16. Al-Oboudi L. Impact of breakfast eating pattern on nutritional status, glucose level, iron status in blood and test grades among upper primary school girls in Riyadh City, Saudi Arabia. Pakistan J Nutr. 2010;9(2):106-11. 
17. Gibney M, Margetts B, Kearney J, Arab L. Gizi kesehatan masyarakat. Jakarta: Penerbit Buku Kedokteran EGC; 2008.

18. Powell C, Walker S, Chang S, GranthamMcGregor M. Nutrition and education: a randomized trial of the effects of breakfast in rural primary school children. Am Soc Clin Nutr. 1998;68:873-9.

19. Cueto $S$. Breakfast and dietary Balance: the en kid study (breakfast and performance). Public Health Nutr. 2001;4(6A):1429-31.

20. Departemen Kesehatan RI. Laporan nasional riset kesehatan dasar tahun 2010. Jakarta: Badan Penelitian dan Pengembangan Kesehatan Depkes RI; 2010.

21. Departemen Kesehatan RI. Riset kesehatan dasar laporan nasional 2007. Jakarta: Badan Penelitian dan Pengembangan Kesehatan Rl; 2008.

22. Departemen Kesehatan RI. Laporan riset kesehatan dasar 2007 Provinsi Nusa Tenggara Timur. Jakarta: Badan Penelitian dan Pengembangan Kesehatan Rl; 2008.

23. Affenito S, Thompson D, Barton B, Franko D, Daniels S, Obarzanek E, et al. Breakfast consumption by African-American and White Adolescent Girls correlates positively with calcium and fiber intake and negatively with body mass index. Am Diet Assoc. 2005;105(6):938-45.

24. Barton B, Eldridge A, Thompson D, Affenito $S$, Striegel-Moore, RH Franko D, Albertson A, et al. The relationship of breakfast and cereal consumption to nutrient intake and body mass index: the national heart, lung, and blood institute growth and health study. Am Diet Assoc. 2005;105(9):1383-9.
25. Stang J, Story M. Guidelines for adolescent nutrition services. Minneapolis: Center for Leadership, Education and Training in Maternal and Child Nutrition, Division of Epidemiology and Community Health, School of Public Health, University of Minnesota; 2005.

26. Soedarsono M. Breakfast for stamina. Surabaya: Penerbit Liris; 2012.

27. Hardinsyah. Proceedings of the 2012 healthy breakfast symposium. Jakarta: Pergizi Pangan Indonesia; 2012.

28. Notoatmodjo S. Pendidikan dan perilaku kesehatan. Jakarta: Rineka Cipta; 2003.

29. Pelto G, Levitt E, Thaira I. Improving feeding practices: current patterns, common constraints, and the design of interventions. Nutr Bull. 2003;24(1):45-82.

30. Almatsier S. Prinsip dasar ilmu gizi. Jakarta: Gramedia Pustaka Utama; 2009.

31. Azwar A. Kecenderungan masalah gizi dan tantangan di masa datang. Pertemuan Advokasi Program Perbaikan Gizi Menuju Keluarga Sadar Gizi. Jakarta: Dirjen Bina Kesmas Depkes; 2004.

32. Suhardjo. Perencanaan pangan dan gizi. Jakarta: PT Bumi Aksara; 2005.

33. Suryana. Keperawatan anak untuk Siswa SMK. Jakarta: Penerbit Buku Kedokteran EGC; 1996.

34. Dekker L, Mora-Plazas M, Marin C, Baylin, Villamor E. Stunting associated with poor socioeconomic and maternal nutrition status and repiratory morbidity in Colombian School children. Food Nutr Bull. 2010;31:242-50. 